\title{
Knowledge Management Perception in Kurdistan Region of Iraq
}

\author{
Shram Shawkat \\ Tishk International University, Business and Administration Department, Sulemania, Iraq \\ shram.shawkat@std.tiu.edu.iq \\ Salim Demir \\ International Burch University, Business and Administration Department, Sarajevo, Bosnia and Herzegovina \\ salim.demir@gmail.com
}

DOI: 10.47299/bsjmm.v2i1.65

\begin{abstract}
The aim of this paper is to understand what knowledge management in general is and what factors affect knowledge management. For starters, we will look at what knowledge management is and how we can use it properly, then we will look at the different factors that make up good knowledge management, and lead firms and institutions into success and better outcome. There are a lot of factors that contribute and affect it overall, but the focus is on four main factors. These factors are the leader and manager's behavior, the teamwork they do, the dynamic and reconfiguration capabilities. A survey was performed to get a better understanding of the situation and hear the problems from different employees' perspectives. The research allows readers to get a better understanding of the issues and problems that are ongoing in universities. A lot of these are results of how the manager in a department in organizations behaves and how the working environment is as well as how well the organization manages to acquire, keep, and share information while getting rid of outdated information. We will be looking at how efficiently firms and institutions in the Kurdistan Region apply knowledge management techniques and whether they do it properly. If we find out that the Kurdistan Region companies and institutions use knowledge management properly and to the best interest of their work, then we can safely say that the Kurdistan Region is in a good state.
\end{abstract}

Keywords: knowledge management, performance, Kurdistan, Iraq

\section{Introduction}

It is clear that every organization has a vision and plan that is right for its clients and owners (Michlitsch, 2000; Mohammed et al., 2020). The organization will thrive in the long term by recognizing potential clients and offering them what they want (Demir, 2019). Therefore, administrators should struggle to reach effective internal and external marketing strategies to improve and develop long term strategies for the sustainable competitive advantages in the market (Budur \& Poturak, 2020, 2021; Torlar et al., 2021). Accordingly, workforce will be adopted to these plans to attract more customers to have a contribution in the strategies (Demir et al., 2019; Mohammed et al., 2020; Zaim et al., 2020). In this respect, researchers noted that quality management systems and knowledge management strategies are some of the important tools that improve the organizational success in the market (Acar et al., 2017; Demir et al., 2020, 2021; Zaim et al., 2018).

Organizations exist for the certain purposes (Budur \& Demir, 2019; Mohamed et al., 2019). Among their objectives, making profit and surviving in the long term is vital important (Alareefi et al., 2019; Jones, 2013). So that, leaders and managers have to focus on the success triggers in the organization to motivate and transform this synergy into performance that improves the productivity and power of the organization in the market (Budur, 2018b; Demir \& Bulut, 2018; Sahin, 2014; Torlar et al., 2019). 
Accordingly, researchers discuss the type of leadership styles that foster organizational effectiveness in the market to compare with other styles (Abdulla et al., 2020; Faeq, 2020; Kamal \& Shawkat; 2020). So that, the style of knowledge oriented and knowledge supportive managers have positive impact on organizational success (Almatrooshi et al., 2019; Alneadi et al., 2020). In order to create a system, based on good communication and skills, companies have to perform a process, known as knowledge management (Demir et al., 2021). Knowledge management is using the knowledge and information in one business or company or any other workplace as efficiently as possible to improve knowledge practices that companies utilize for success (Zaim, 2006).

Nemati et al. (2002) noted that knowledge starts being a valuable asset for a company after it is codified and categorized in a meaningful format. Codified knowledge can be used for current operations or stored for re-access. Similarly, Zaim (2006) states that codification has to be in line with the organizational objectives so that it can be modified to be in line with current use and future updates by the organization. Hurmelinna et al. (2018) maintain that more and appropriate codification of knowledge facilitates its understanding and learning by partners. Additionally, well codified knowledge increases the effectiveness of knowledge transfer and utilization (Schulz and Jobe, 2001). Shulz and Jobe (2001) also suggest some ways of reaching effective codification including expert codes, reports, memos, codes in a language format, polices, knowledge maps, organizational dictionaries, and simulators.

According to Grant (1996) a flexible, consistent, and frequent evaluation of knowledge increases a company's efficiency of its knowledge management abilities. Bierly et al. (2000) maintain that consistent knowledge management stimulates a company's sustainable performance. Palacios Marqués and José Garrigos (2006) show that KM practices promote organizational innovativeness and performance as compared to their competitors. Kianto et al. (2018) found a positive relationship between a company's KM practices and market performance. They also point out that managers play a significant role in this positive correlation. Dzenopoljac et al. (2018) investigated the impact of KM practices on a company's innovative performance and noted a significant positive correlation between KM practices and innovative performance of firms.

For the purpose of this research, we are using a survey that we will give to firms in order to know if they are managing their knowledge properly and that they are making good use of their employee's knowledge and skills. The survey of the study is divided into five sections along with an extra follow up section. The first part of the survey gives enough insight on how the firm is generating information and knowledge and how it encourages its employees to further develop their skills and knowledge. In this section titled "Knowledge Generation and Development" we take a look at how the firm treats its employees when it comes to new ideas and innovation. This is after we took a look at how important it is for firms to help employees' creativity grow further. Just like every other survey, the survey taker is asked to rate each situation on a scale of one to five, one being disagree and five being agree. After we find out how well the work environment is and how encouraging it is for employees, we then go on to the second part of the survey titled, "Knowledge codification and storage".

In the second section of the survey, we take a look at how well data is organized in the firm and whether the knowledge and information is used properly. For this, we will be asking if the firm is storing information regarding their product properly, and whether they have a suitable database system to do so. Just like the previous section, this section will also be answered on a scale of 1 to 5 , five being agree and 1 being disagree. A great and very important secret for the success of a business 
is to have constant up to date information regarding your clients, your product, your rivals, and many more. We make sure the person that fills out this survey will respond to all of these, and in case they are not able to provide and keep up to date data and information, we will provide them with guidance to do so. After this part of the survey comes the third part which is titled "Knowledge Sharing". In this section of the survey, we emphasize on how well the different parts of the firm communicate with each other. It is definitely vital and important for managers to communicate with their employees and for the employees to be in constant contact with the customers and clients (The State of Queensland, 2019). Therefore, in this part we start with asking starters whether employees are in contact through email, phones, or even social media accounts. This will be a starting ground for better knowledge control in a firm and will lead to further development. We have put a very crucial question in this section and that is when we ask if the survey taker believes that communication leads to better work or not. The answer to this question tells us a lot about the nature of the person when it comes to work. This part of the survey encourages colleagues to take part in sessions of information and knowledge sharing and make sure what was at one point only doable by one person will soon be done by more.

In the fourth section of the survey, we focus on adaptation of the knowledge and how it is put to work. This section of the survey is called "Knowledge Utilization". The aim of this section is to know to what extent is the knowledge and information and skills of the employees put to good use. It is very important to know if the firm has accurate and proper decision making that serves in the best interest of the firm economically and realistically. Along with that, we also need to see if initiatives are taken good care of and the managing team is always open to new ideas. The last section of the questionnaire is titled as "Sustainability". In my opinion this is the most important part of any business. Whenever a person or a firm comes up with a new idea, they need to have a sustainability plan for the future to see if this plan is actually suitable to be put into practice, and how durable it is, and if it is going to withstand the obstacles with time. In order for an idea to be sustainable, we have to take into consideration any possible change in the future, whether that is a change in staff, a change in circumstances, or a change in the financial status of the business.

\section{Literature Review}

It is quite important for institutions to have a knowledge management system in their workplace. The system helps knowledge be developed, transferred, and even exchanged faster, whether it is between employees or different firms (Zaim et al., 2019). Knowledge management systems also create room for development of individual employees and increase the chance for creativity and innovation from the employees (Budur, 2018). A creative employee could successfully take advantage of the knowledge management system and further develop their ideas in the firm (Budur \& Demir, 2019).

Knowledge is the gateway to competitiveness (Demir et al., 2021). The difficulty for businesses needing inclusion in information-intensive sectors of the global business is to organize themselves so that they can recognize the importance of knowledge systems, which commercial knowledge is unique in kinds of transforming theoretical knowledge into practical knowledge that add values to the organizational success (Demarest, 1997). Growing analytical awareness viewpoints for organizational knowledge, i.e. moving from the level of operation of human knowledge to organizational knowledge (Antunes \& Pinheiro, 2020). The learning organization tends to be constantly growing the expertise and awareness of individuals, encouraging collaborative learning through coordinating learning (Poturak et al., 2020; Torlak et al., 2021) and even creating organizational memory (Ferraris et al., 
2019). KM's diverse methods rely on generating, disseminating, storing and integrating current or new knowledge (Coombs \& Hull, 1998; Mardani et al., 2018). Wiig (1997) argues that KM's goal is "to maximize the efficiency and returns of the knowledge-based enterprise from its knowledge assets and to constantly renew them". Knowledge management processes have been thoroughly reviewed in the literature. Those are in terms of generation, codification, coordination and exchange (Zaim et al., 2018). In addition, Zaim et al. (2007) presented empirical data on the effect of generation, storage, exchange and consumption of knowledge on efficiency.

Furthermore, it has been noted that there is a positive relationship between knowledge sharing and organizational performance (Ali et al., 2019). However, more evidence on this relationship is needed in the literature. As Muhammed and Zaim (2020) pointed out, 'What kind of relationship exists between knowledge sharing and performance, and what factors influence the relationship?". Accordingly, the current research contributes to literature by discussing information management processes in Kurdish firms through the provision of their average impressions.

\section{Research Methodology}

To further investigate the importance of this paper, survey questionnaire has been conducted in order to collect data about knowledge management at Kurdistan region of Iraq organization. The questionnaire contains twelve questions, which are adapted from Shamin et al. (2019). The survey has been conducted by Google forms. The number of the respondents was about 209 employees of the various companies from Kurdistan Region of Iraq. Further, the responses have been evaluated based on the five Likert scale, whereas 1 represented that "Strongly Disagree" and 5 represented "Strongly Agree".

What we have done is to elaborate the different uses of knowledge management globally beforehand. In order to be able to understand something and conduct a research on it, we have to first understand every aspect of it. For that purpose, we researched all the different types of knowledge management systems and researched how different firms and institutions use them. We later on went and sent out our questionnaire survey to different firms and institutions within the Kurdistan Region, and asked them about their awareness of knowledge management and whether they apply knowledge management to further improve their work. Through this survey, we would filter their answers based on category and then combine our results in order to make a conclusion out of it.

\section{Demographic Information}

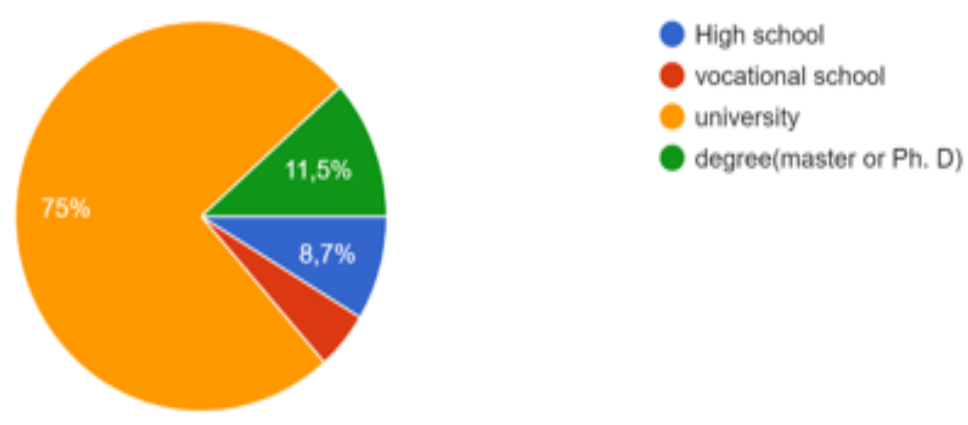

Figure 1 Education level of samples

Figure 1 represents the education level of the samples from whom we have collected data. Given in 
the figure, $75 \%$ answered that they received a university education, $11.5 \%$ of the people surveyed answered that they received a higher degree of education (Masters, or Ph. D), 8.7\% of the participants stated that they only received a high-school education, and lastly, $4.8 \%$ of the participants only received an education in vocational schools.

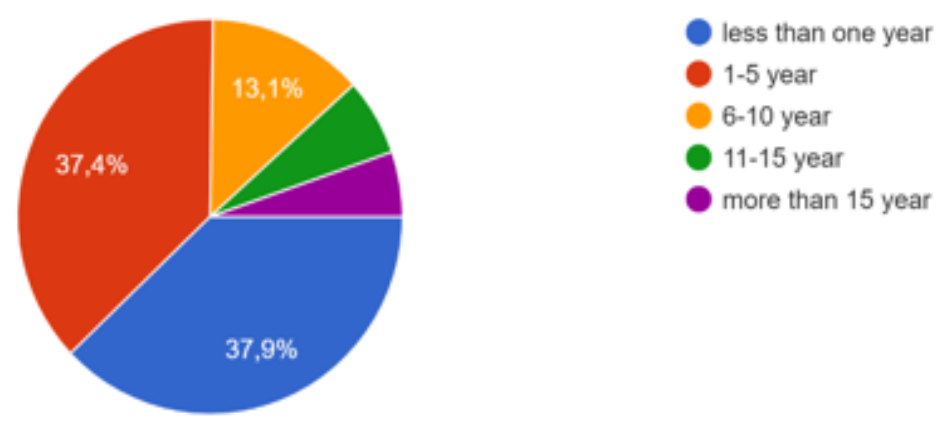

Figure 2 Experience

Given in the Figure 2, 37.9\% of them has less than one year of experience working in their respective companies. However, $37.4 \%$ of the participants has been working for 1-5 years in their companies, $13.1 \%$ of the people surveyed has been working in their companies for $6-10$ years, $5.5 \%$ of the participants has been working in the same company for $11-15$ years, and lastly $6.1 \%$ of the participants has been working in the same company for more than 15 years.

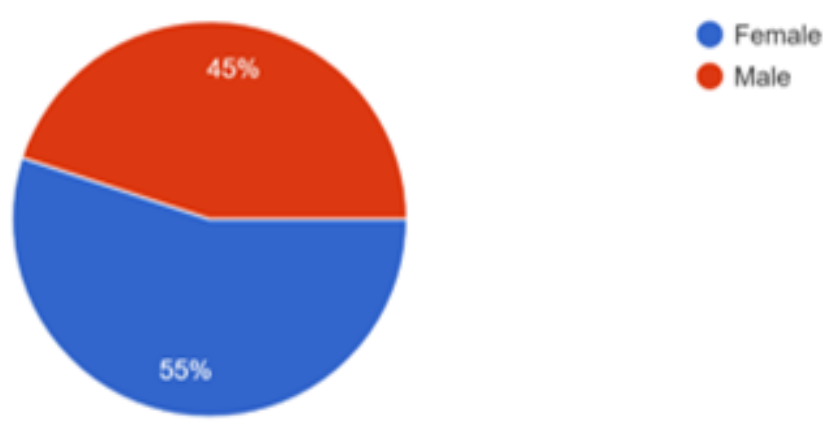

Figure 3 Gender of the sample

Among the people who participated in this survey, while $45 \%$ of them were males and $55 \%$ of them were females.

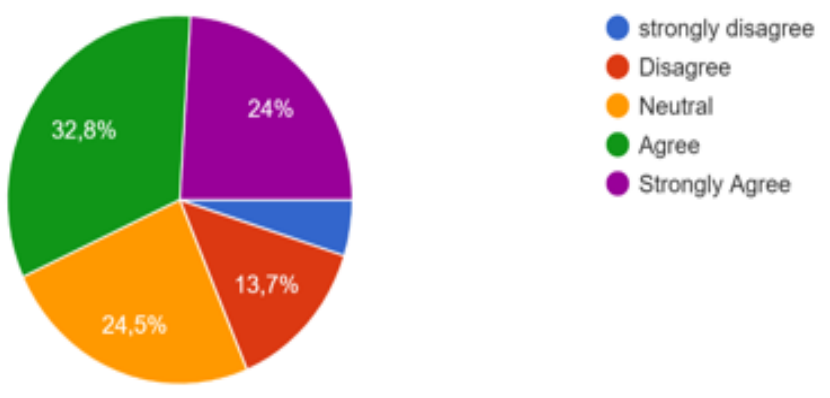

Figure 4 Searching for new knowledge and information 
When surveyed about whether their companies search for new knowledge and information about new products or services in the market, $32.8 \%$ of the participants answered that their companies indeed do that. However, $24.5 \%$ of the participants answered that they were neutral on the matter, perhaps because their companies perform that to a certain degree, or they aren't aware whether their companies conduct searches or not. Moreover, $24 \%$ of the survey takers answered that they strongly agree that their companies search for knowledge about products or services in the market. On the other side, $13.7 \%$ of the survey takers answered that they disagree that their companies perform such tasks. Lastly, $5 \%$ of the participants strongly disagreed that their companies conduct searches to obtain information and knowledge about products or services in the market.

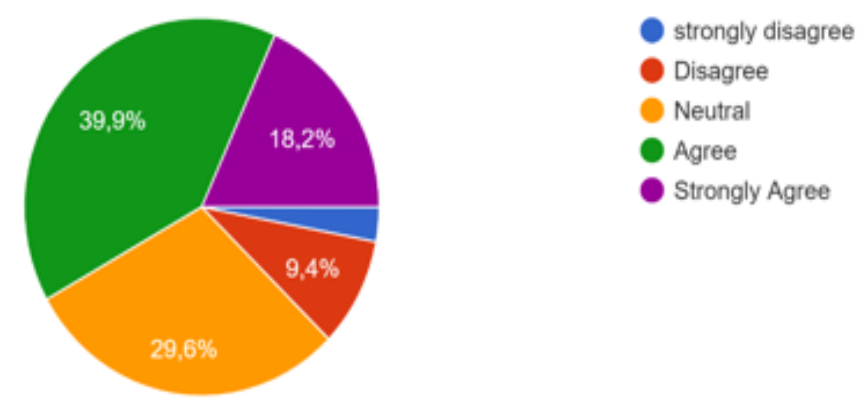

Figure 5 Processes for acquiring new knowledge

Among the participants of this survey, $39.9 \%$ of them answered that their organizations have processes to obtain or acquire knowledge about competition in the industry. Secondly, $29.6 \%$ of the participants of this survey were neutral about whether their companies provide such processes because either they lacked the knowledge about it or their companies perform these processes to a certain degree. However, $18.2 \%$ of the survey takers answered that they strongly agreed that their companies perform such processes. On the other side of the spectrum, $9.4 \%$ of the participants answered that they disagree that their company performs such tasks. Lastly, $2.9 \%$ of the survey takers answered that they strongly disagree that their companies perform these tasks.

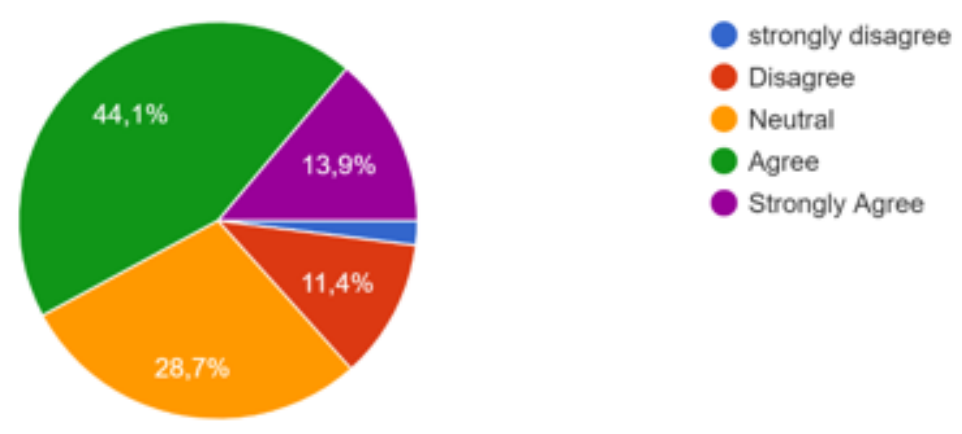

Figure 6 Capability to generate new knowledge

When asked whether their organizations possess the means for generating new knowledge from existing knowledge, $44.1 \%$ of the participants of the survey answered that they agree that their companies possess these mechanisms. Secondly, $28.7 \%$ of the participants answered that they were neutral, perhaps due to their lack of knowledge of such processes in their companies. Moreover, $13.9 \%$ of the survey takers answered that they strongly agree that their organizations possess such 
processes to generate new knowledge whilst $11.4 \%$ of the survey participants stated that they disagree that their organizations have such processes. Finally, $1.9 \%$ of the survey takers said that they strongly disagree that their companies possess such processes.
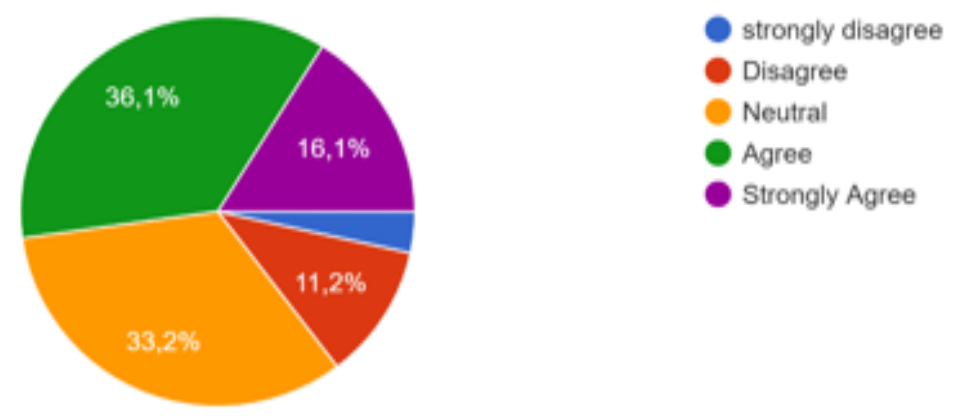

Figure 7 Capability to transfer knowledge

When asked whether their organizations perform processes for transferring organizational knowledge to their employees, $36.1 \%$ of the participants stated that they agreed. $33.2 \%$ of the participants stated that they are neutral about whether their organizations possess such processes; perhaps because they lack knowledge about such processes existing in their organizations. $16.1 \%$ of the survey takers answered that they strongly agree stating that their organizations definitely possess such processes. Moreover, $11.2 \%$ of the survey takers say that they disagree that their organizations conduct such processes. Finally, $3.4 \%$ of the survey takers said that they strongly disagree whether their organizations possess such processes.

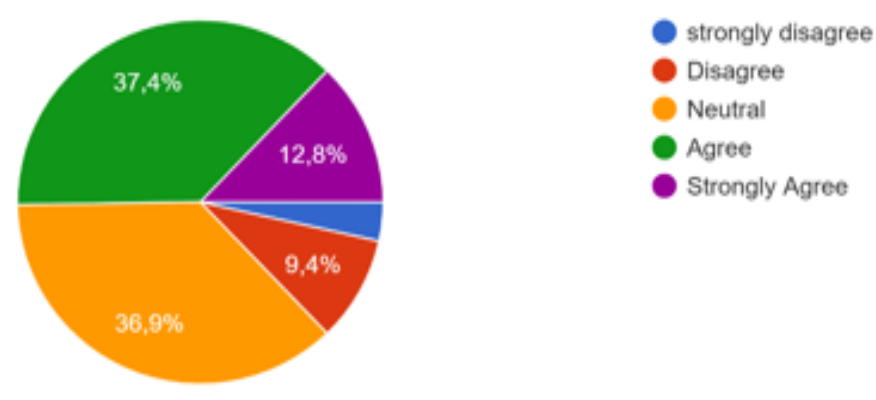

Figure 8 Internalizing capability of knowledge

When the participants of the survey were asked whether their organizations possess processes from absorbing knowledge from individuals into the organizations, $12.8 \%$ stated that they strongly agreed. $37.4 \%$ of the participants stated that they agreed that they possess such processes, $36.9 \%$ of the survey takers stated that they are neutral whether their organizations possess such processes while $9.4 \%$ of the participants stated that they disagree that their organizations possess such processes. Lastly, $3.5 \%$ of the participants stated that they strongly disagree their organizations possess such processes. 


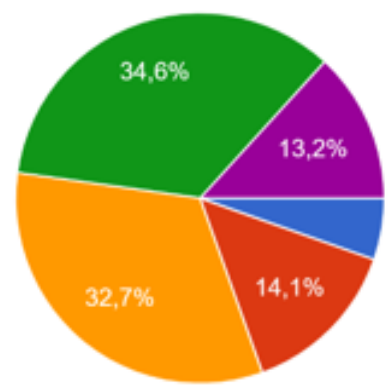

strongly disagree

Disagree

Neutral

Agree

Strongly Agree

Figure 9 Capability to absorb knowledge from business partners

In another segment of the survey, participants were asked whether their organizations have processes for absorbing knowledge from business partners and transfer it into the organization, $34.6 \%$ of the participants agreed that their organizations possessed such processes, $13.2 \%$ of the participants strongly agreed that they possessed such processes within their organizations, $32.7 \%$ of the participants stated that they were neutral; perhaps they were uncertain about the matter. On the other hand, $14.1 \%$ of the participants stated that they disagreed whether their organizations possessed such processes. Lastly, $5.4 \%$ of the participants strongly disagreed that such processes existed within their organizations.
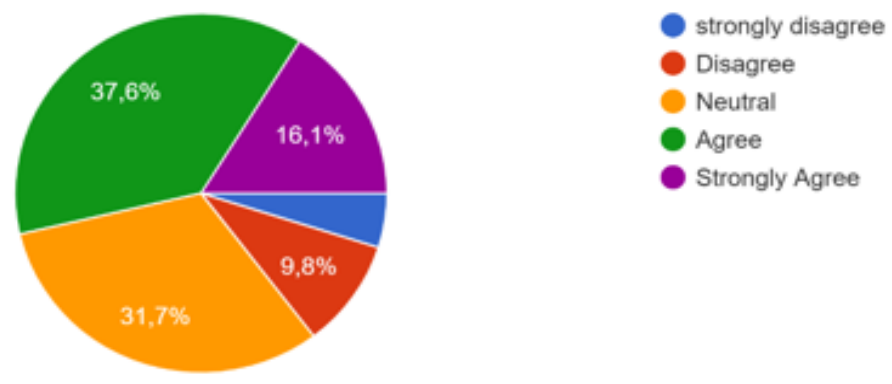

Figure 10 Capability to integrate different sources of knowledge

In another part of the survey, participants were asked whether their organizations possessed processes for integrating different sources and types of knowledge. $37.6 \%$ of the participants agreed that their organizations possessed such processes, $16.1 \%$ of the participants strongly agreed that they possessed such processes within their organizations, $31.7 \%$ of the participants stated that they were neutral stating that perhaps they were uncertain about the matter. On the other hand, $9.8 \%$ of the participants stated that they disagreed whether their organizations possessed such processes. Lastly, $4.8 \%$ of the participants strongly disagreed that such processes existed within their organizations. 


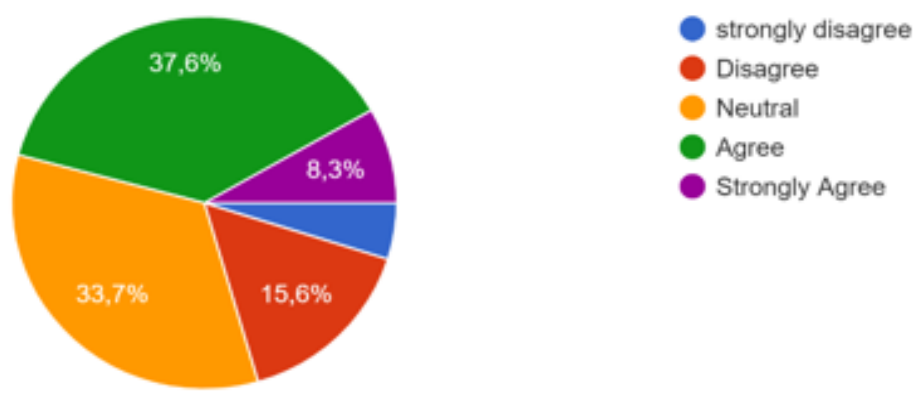

Figure 11 Capability to eliminate the outdated knowledge

In another part of the survey, participants were asked whether their organizations possessed processes for replacing outdated knowledge. $37.6 \%$ of the participants agreed that their organizations possessed such processes, $8.3 \%$ of the participants strongly agreed that they possessed such processes within their organizations, $33.7 \%$ of the participants stated that they were neutral stating that perhaps they were uncertain about the matter. On the other hand, $15.6 \%$ of the participants stated that they disagreed whether their organizations possessed such processes. Lastly, $4.8 \%$ of the participants strongly disagreed that such processes existed within their organizations.

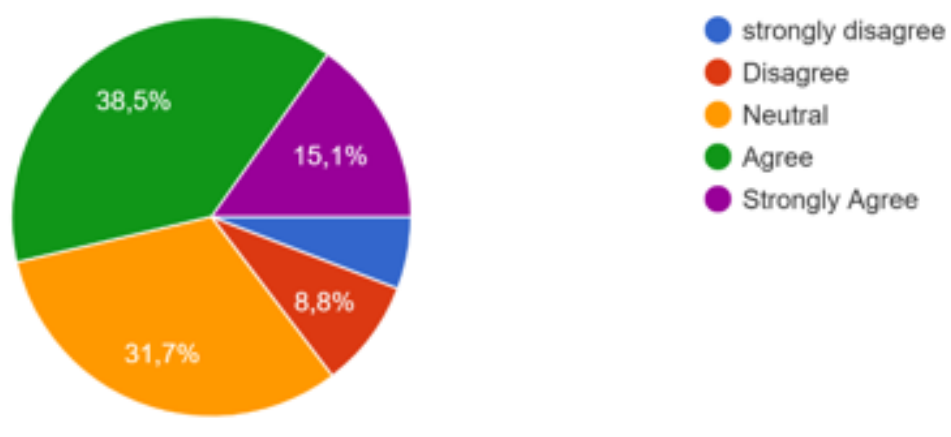

Figure 12 Capability to convert the knowledge into the plans

Another part of the survey asked participants whether their organizations possessed processes for converting competitive intelligence into plans of action. 38.5\% of the participants agreed that their organizations possessed such processes, $15.1 \%$ of the participants strongly agreed that they possessed such processes within their organizations, $31.7 \%$ of the participants stated that they were neutral stating that perhaps they were uncertain about the matter. On the other hand, $8.8 \%$ of the participants stated that they disagreed whether their organizations possessed such processes. Lastly, $5.9 \%$ of the participants strongly disagreed that such processes existed within their organizations. 


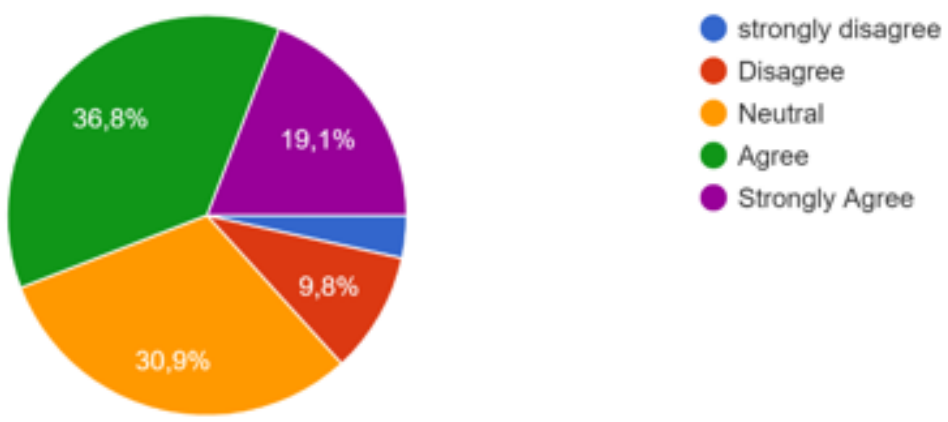

Figure 13 Capability to learn from the mistakes

Yet another segment of the survey asked participants whether their organizations possessed processes for applying knowledge learned from mistakes. Given in the Figure $13,36.8 \%$ of the participants agreed that their organizations possessed such processes, $19.1 \%$ of the participants strongly agreed that they possessed such processes within their organizations, $30.9 \%$ of the participants stated that they were neutral stating that perhaps they were uncertain about the matter. On the other hand, $9.8 \%$ of the participants stated that they disagreed whether their organizations possessed such processes. Lastly, $3.4 \%$ of the participants strongly disagreed that such processes existed within their organizations.

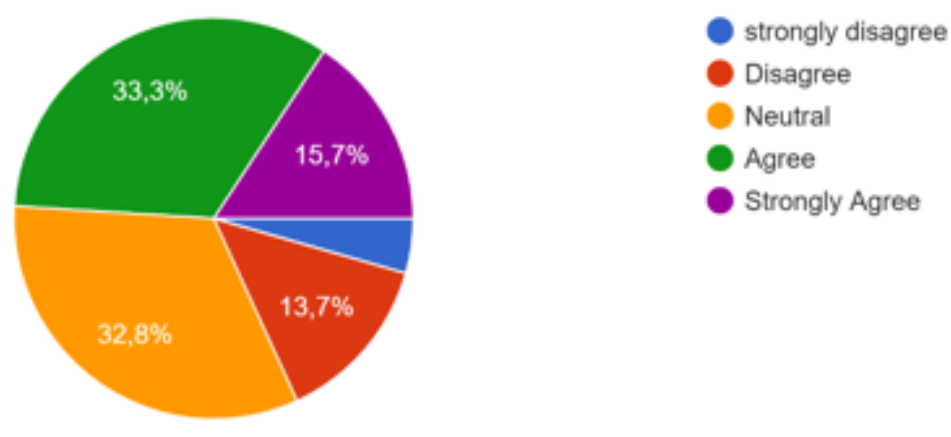

Figure 14 Capability to use the knowledge to response to the market

Participants of the survey were asked whether their organizations are able to locate and apply knowledge to changing competitive conditions. Based on the results in Figure 14, 33.3\% of the participants agreed that their organizations possessed such processes, $15.7 \%$ of the participants strongly agreed that they possessed such processes within their organizations, $32.8 \%$ of the participants stated that they were neutral, as they were uncertain about the matter. On the other hand, $13.7 \%$ of the participants stated that they disagreed whether their organizations possessed such processes. Lastly, $4.5 \%$ of the participants strongly disagreed that such processes existed within their organizations. 


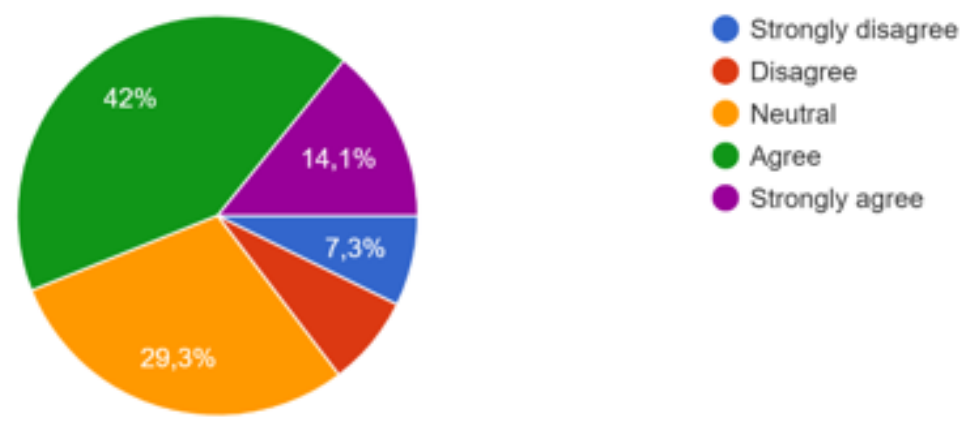

Figure 15 Capability to protect the knowledge

The last part of the survey asked participants whether their companies clearly communicate the importance of protecting knowledge. Given in the Figure 15, 42\% of the participants agreed that their organizations possessed such processes, $14.1 \%$ of the participants strongly agreed that they possessed such processes within their organizations, $29.3 \%$ of the participants stated that they were neutral, becasue they were uncertain about the matter. On the other hand, $7.3 \%$ of the participants stated that they disagreed whether their organizations possessed such processes. Lastly, $7.3 \%$ of the participants strongly disagreed that such processes existed within their organizations.

\section{Conclusion}

In conclusion of our research and our long and hard work surveying different employees from different firms and institutions within the Kurdistan region, our speculations are as follows:

Vast majority of the employees questioned in the survey showed agreement to our questions and said that their firms apply knowledge management procedures. Our result curve is more towards the agreement side, which gives us hope for industries and firms in the Kurdistan Region, knowing that they function in accordance to plans and proper steps. If our results had been negative, we would have to come up with ways to further introduce firms in Kurdistan to knowledge management and focus on the different steps of knowledge management.

But it turns out that firms in the Kurdistan region have efficient ways to control knowledge and information. Employees get necessary trainings when required and turns out that firms do listen to employees when it comes to decision making and therefore enables decision making easier for everyone. Along with that firms usually give employees a chance to present their new ideas and make sure they have enough room for further development and to further develop their talents, and skills. However, there are firms who still do not use knowledge management properly. As a result of this research, we recommend for all firms to start efficient use of knowledge management. Through this process, companies and firms will perform better in the market and this will increase the chances for a more competitive market with better products. It will also give user firms an advantage in the competitive market, because their results will be better. The use of knowledge management will also aid in reducing cost, because firms will no longer need to spend unnecessary money and every expense will go through different steps of close analysis. 


\section{References}

Abdulla, N., Wrya, H., \& Durmaz, O. (2020). Green product perception in Kurdistan Region of Iraq. Black Sea Journal of Management and Marketing, 1(1), 1-15.

Acar, M. F., Tarim, M., Zaim, H., Zaim, S., \& Delen, D. (2017). Knowledge management and ERP: Complementary or contradictory? International Journal of Information Management, 37(6), 703-712.

Alareefi, N. A. O. M., Abuelhassan, A. E., Khalifa, G. S. A., Nusari, M., \& Ameen, A. (2019). Employee's Innovative Behaviour: Evidence from Hospitality Industry. Pakistan Journal of Social Sciences, 16(1), 14-29.

Ali, A.A., Panneer Selvam, D.D.D., Paris, L., \& Gunasekaran, A. (2019). Key factors influencing knowledge sharing practices and its relationship with organizational performance within the oil and gas industry. Journal of Knowledge Management, 23(9), 1806-1837.

Almatrooshi, M. J. A., Khalifa, G. S., Ameen, A., Hossain, M. S., \& Morsy, M. A. (2020). The role of knowledge-oriented leadership and knowledge sharing to manage the performance of Ministry of Interior in UAE. International Journal on Recent Trends in Business and Tourism (IJRTBT), 4(2), 9-17.

Alneadi, K. M., Almatrooshi, M. J., Khalifa, G. S., El-Aidie, S. A., Alhaj, B. K., \& Morsy, M. A. (2020). Linking knowledge oriented leadership and innovation towards organizational performance. Academic Leadership, 21(4), 107-118.

Antunes, H. D. J. G., \& Pinheiro, P. G. (2020). Linking knowledge management, organizational learning and memory. Journal of Innovation \& Knowledge, 5(2), 140-149.

Bierly, P. E., Kessler, E. H., \& Christensen, E. W. (2000). Organizational learning, knowledge and wisdom. Journal of Organizational Change Management, 13(6), 595-618.

Budur, T. (2018a). Analytic hierarchy process to evaluate corporate image, trust, and switching cost of GSM Operators: A case of Kurdistan Region of Iraq. International Journal of Social Sciences \& Educational Studies, 5(2), 241-250

Budur, T. (2018b). The impact of Al-Ghazali's virtues on organizational commitment and performance: A case Study at private education institutions in Kurdistan Region of Iraq. Icabep, Erbil-Iraq, 2, p21.

Budur, T. (2020). Impact of transformational leadership on customer satisfaction: mediating effects of employee performance and organizational citizenship behaviors. (Unpublished doctoral dissertation). International Burch University.

Budur, T., Top, C., Durmaz, O., \& Demir, A. (2019). Elaborating the Employees' Evaluation of Their Leaders Based on Gender, Experience, and Education.

Budur, T., \& Demir, A. (2019a). Leadership effects on employee perception about CSR in Kurdistan Region of Iraq. International Journal of Social Sciences \& Educational Studies, 5(4), 182-194.

Budur, T., \& Demir, A. (2019b). Leadership perceptions based on gender, experience, and education. International Journal of Social Sciences \& Educational Studies, 6(1), 142-154.

Budur, T., \& Poturak, M. (2021). Employee performance and customer loyalty: mediation effect of customer satisfaction. Middle East Journal of Management.

Budur, T., \& Poturak, M. (2021). Transformational leadership and its impact on customer satisfaction. Measuring mediating effects of organisational citizenship behaviours. Middle East Journal of Management, 8(1), 67-91.

Budur, T., Faraj, K. M., \& Karim, L. A. (2019). Benchmarking operations strategies via hybrid model: A case study of caférestaurant sector. Amazonia Investiga, 8, 842-854.

Budur, T., Rashid, C. A., \& Poturak, M. (2018). Students' perceptions on university selection, decision making process: A case study in Kurdistan Region of Iraq. International Journal of Social Sciences \& Educational Studies, 5(1), $133-144$.

Coombs, R., \& Hull, R. (1998). Knowledge management practices' and path-dependency in innovation. Research Policy, 27(3), 239-256.

Demarest, M. (1997). Understanding knowledge management. Long Range Planning, 30(3), 321-384. 
Demir, A., Shawkat, S., Majeed, B.N., \& Budur, T. (2019). Fuzzy AHP and VIKOR to select best location for bank investment: case study in Kurdistan Region of Iraq. In Effective investments on capital markets, Tarczyn'sk W, Nermend K (eds). Springer: Cham; 485-510.

Demir, A. (2019). A Benchmarking of service quality in telecommunication services: Case study in Kurdistan Region of Iraq. International Journal of Social Sciences \& Educational Studies, 5(3), 216.

Demir, A. (2019). The impact of strategic operations management decisions on shoppers' wellbeing. Asian Academy of Management Journal, 24(1).

Demir, A. (2020). Impact of Internal Marketing on the Customer Perceptions in SMEs. International Journal of Services and Operations Management. DOI: 10.1504/IJSOM.2020.10033103

Demir, A. (2020). InterContinental Review for Diffusion Rate and Internal-External Benefits of ISO 9000 QMS. International Journal of Productivity and Quality Management. DOI: 10.1504/IJPQM.2020.10030912

Demir, A., \& Budur, T. (2019). Roles of leadership styles in corporate social responsibility to non-governmental organizations (NGOs). International Journal of Social Sciences \& Educational Studies, 5(4), 174-183.

Demir, A., \& Bulut, I. (2018). A New Model for Respected Meetings. Procedia Computer Science, 126, 1637-1655.

Demir, A., Aydinli, C., \& Talaat, K. (2015). Optimizing human resources capacity and performance of Newroz Telecom company by proposing queuing theory. International Journal of Social Sciences \& Educational Studies, 2(1), 28.

Demir, A., Budur, T., \& Heshmati, A. (2020). Antecedents of trust, corporate image, and switching costs: a case in telecommunication services in the Kurdistan region of Iraq. International Journal of Mobile Communications, 19(1), 5374.

Demir, A., Budur, T., Hiwa, M., \& Heshmati, A. (2021). Links between knowledge management and organizational sustainability: Does the ISO 9001 certification have an effect? Knowledge Management Research \& Practice (TKMR), DOI: $10.1080 / 14778238.2020 .1860663$

Demir, A., Maroof, L., Khan, N. U. S., \& Ali, B. J. (2020). The role of E-service quality in shaping online meeting platforms: a case study from higher education sector. Journal of Applied Research in Higher Education. DOI: 10.1108/JARHE-082020-0253

Dzenopoljac, V., Alasadi, R., Zaim, H., \& Bontis, N. (2018). Impact of knowledge management processes on business performance: Evidence from Kuwait. Knowledge and Process Management, 25(2), 77-87.

Faeq, M. (2020). Performance evaluation criteria development process for academic staff at universities. Black Sea Journal of Management and Marketing, 1(1), 59-70.

Ferraris, A., Mazzoleni, A., Devalle, A., \& Couturier, J. (2019). Big data analytics capabilities and knowledge management: Impact on firm performance. Management Decision, 57(8), 1923-1936.

Grant, R. M. (1996). Toward a knowledge - based theory of the firm. Strategic Management Journal, 17(S2), $109-122$.

Hurmelinna-Laukkanen, P., Olander, H., \& Von Zedtwitz, M. (2018). The nature and dimensions of knowledge mobility for competitive advantage. In Knowledge Management in the Sharing Economy (pp. 169-188). Springer, Cham.

Jones, G. R. (2013). Organizational theory, design, and change. Upper Saddle River, NJ: Pearson.

Kamal, T., \& Shawkat, S. (2020). The impact of dynamic capabilities on knowledge management in Kurdistan Region of Iraq. Black Sea Journal of Management and Marketing, 1(1), 41-48.

Kianto, A., Ritala, P., Vanhala, M., \& Hussinki, H. (2018). Reflections on the criteria for the sound measurement of intellectual capital: A knowledge-based perspective. Critical Perspectives on Accounting, 102046.

Mardani, A., Nikoosokhan, S., Moradi, M., \& Doustar, M. (2018). The relationship between knowledge management and innovation performance. The Journal of High Technology Management Research, 29(1), 12-26.

Marques, D. P., \& Simon, F. J. G. (2006). The effect of knowledge management practices on firm performance. Journal of Knowledge Management.

Michlitsch, J. F. (2000). High-performing, loyal employees: The real way to implement strategy. Strategy \& Leadership, 5(3). DOI: 10.1108/mbe.2001.26705caf.003 
Mohamed, M. S., Khalifa, G. S., Al-Shibami, A. H., Alrajawi, I., \& Isaac, O. (2019). The mediation Effect of Innovation on the relationship between creativity and organizational productivity: An empirical study within public sector organizations in the UAE. Journal of Engineering and Applied Sciences, 14(10), 3234-3242.

Mohammed, K. S., Rashid, C. A., Salih, H. A., \& Budur, T. (2020). The role of online teaching tools on the perception of the students during the lockdown of Covid-19. International Journal of Social Sciences \& Educational Studies, 7(3), 178-190.

Mohammed, S. S., Suleyman, C., \& Taylan, B. (2020). Burnout determinants and consequences among university lecturers. Amazonia Investiga, 9(27), 13-24.

Muhammed, S., \& Zaim, H. (2020). Peer knowledge sharing and organizational performance: the role of leadership support and knowledge management success. Journal of Knowledge Management, 24(10), 2455-2489.

Nemati, H. R., Steiger, D. M., Iyer, L. S., \& Herschel, R. T. (2002). Knowledge warehouse: An architectural integration of knowledge management, decision support, artificial intelligence and data warehousing. Decision Support Systems, 33(2), 143-161.

Poturak, M., Mekić, E., Hadžiahmetović, N., \& Budur, T. (2020). Effectiveness of transformational leadership among different cultures. International Journal of Social Sciences \& Educational Studies, 7(3), 119-129.

Sahin, O. (2014). An investigation of student satisfaction factors. Journal of Research in Business and Management, 2(6), 81.

Schulz, M., \& Jobe, L. A. (2001). Codification and tacitness as knowledge management strategies: An empirical exploration. The Journal of High Technology Management Research, 12(1), 139-165.

Shamim, S., Cang, S., \& Yu, H. (2019). Impact of knowledge-oriented leadership on knowledge management behaviour through employee work attitudes. The International Journal of Human Resource Management, 30(16), 2387-2417.

Torlak, N. G., Demir, A., \& Budur, T. (2019). Impact of operations management strategies on customer satisfaction and behavioral intentions at café-restaurants. International Journal of Productivity and Performance Management, 69, (9), 1903-1924.

Torlak, N. G., Demir, A., \& Budur, T. (2021). Decision-making, leadership and performance links in private education institutes. Rajagiri Management Journal. DOI: 10.1108/RAMJ-10-2020-0061.

Torlak, N. G., Kuzey, C., Dinc, M.S., \& Budur, T. (2021). Links connecting nurses' planned behavior, burnout, job satisfaction and organizational citizenship behavior. Journal of Workplace Behavioral Health. DOI:10.1080/15555240.2020.1862675

Wiig, K. M. (1997). Knowledge management: An introduction and perspective. Journal of knowledge Management, 1(1), 614.

Zaim, H. (2006). Knowledge management implementation in IZGAZ. Journal of Economic and Social Research, 8(2), 1-25.

Zaim, H., Demir, A., \& Budur, T. (2020). Ethical leadership, effectiveness and team performance: An Islamic perspective. Middle East Journal of Management, 8(1), 42-66.

Zaim, H., Keceli, Y., Jaradat, A., \& Kastrati, S. (2018). The effects of knowledge management processes on human resource management. Journal of Science and Technology Policy Management, 9(3), 310-328.

Zaim, H., Muhammed, S., \& Tarim, M. (2019). Relationship between knowledge management processes and performance: Critical role of knowledge utilization in organizations. Knowledge Management Research \& Practice, 17(1), 24-38. 